\title{
SELF-CURING CONCRETE UNDER SULFATE ATTACK
}

\begin{abstract}
A. A. BASHANDY ${ }^{1}$
Self-curing concrete $\mathrm{SC}$ is a concrete type that can be cured without using any external curing regimes. It can perform by several methods such as using lightweight aggregate or chemical agents. In this research chemical curing agent is used to produce SC. This paper reports the results of a research study conducted to evaluate the effect of sulfates on the performance of self-curing concrete compared to ordinary concrete. Samples are immersed in sodium sulfate $\mathrm{Na} 2 \mathrm{SO} 4$ solution of $4 \%$ concentration. Results are measured in terms of compressive strength, tensile strength, flexural strength and mass loss. It was found that the rate of strength loss is noticed at ordinary concrete compared to SC concrete. Sulfate resistance is improved when using self-curing concrete. This improvement appears to be dependent on using a chemical curing agent.
\end{abstract}

Keywords: Self-Curing, Polyethylene Glycol, Sulfate, Durability, Concrete

\section{INTRODUCTION}

Curing is the maintaining of a satisfactory moisture content and temperature in concrete during its early stages to produce a suitable structural concrete. The strength and durability of concrete will be developed only if it is cured as soon as required [1]. Curing methods involve either the introduction of water after placing or the reduction in the rate of evaporation from the surface [2]. An internal curing "IC" system could be created by the introduction of a chemical curing agent during the mixing to reduce water evaporation in the concrete and make it effectively self-curing [3, 2]. A feasibility of curing concrete by adding water-soluble chemicals during mixing that reduce water evaporation during setting and hardening of the concrete, making it self-curing, was discussed by several researchers $[4,3,5,6]$. The chemicals' abilities to reduce evaporation from solution

\footnotetext{
${ }^{1}$ Associate Professor, Civil Engineering Department, Faculty of Engineering, Menoufia University, Egypt, e-mail: Eng_ALB@yahoo.com
} 
and to improve water retention in hydrating Portland cement was monitored by measuring weightloss, X-Ray powder diffraction, and thermo-gravimetry. As internal curing maintains saturated conditions within the hydrating cement paste, the magnitude of internal self-desiccation stresses are reduced and long term hydration is increased. IC is particularly effective for the high performance concretes containing silica fume. In cement mortar containing a Type F (ASTM C494) fly ash, the fly ash functions mainly as a diluent at early ages and higher and coarser porosity at early ages result in less autogenous shrinkage $[2,4,7,8]$. Concrete durability is the ability to last a long time without significant deterioration. Durability may be expressed in terms of sulfate or chloride resistance. Sulfates present in soils, groundwater, sea water, decaying organic matter, and industrial effluent surrounding a concrete structure may permeate the concrete and react with existing hydration products. In the presence of calcium hydroxide $(\mathrm{CH})$ and water $(\mathrm{H})$, mono-sulfate hydrate $(\mathrm{C} 3 \mathrm{~A} \cdot \mathrm{CS} \cdot \mathrm{H} 18)$ and calcium aluminates hydrate $(\mathrm{C} 3 \mathrm{~A} \cdot \mathrm{CS} \cdot \mathrm{H} 18)$ react with the sulfate $(\mathrm{S})$ to produce ettringite (C3A-3CS·H32) [9]. The conventional forms of sulfate attack occur where expansive ettringite together with gypsum has been formed due to the sources of sulfates such as sulfates or sulfides in the ground or due to the presence of mobile groundwater or calcium hydroxide, calcium aluminates hydrate and calcium silicate hydrate (for magnesium sulfate) in the cement matrix [10]. The external sulfate attack "ESA" is characterized by the chemical reaction between sulfate ions with the aluminates component, calcium and hydroxyl of hardened Portland cement. The reaction leads to the formation of expansive ettringite and to a lesser extent, gypsum. The reaction, in case where there is enough water present, will cause expansion leading to cracking. This in turn will allow further ingress of sulfates and accelerate the degradation process. For ESA to occur, three conditions must be fulfilled: high permeability of concrete, sulfate-rich environment and presence of water. The ESA related damage manifests itself in several forms including cracking, spalling, loss of strength and adhesion. In hardened conventional concrete, the formation of ettringite by sulfate attack may result in expansion and lead to cracking of the concrete. The conditions under which ettringite formation produces damage in the concrete are uncertain. It should be noted that ettringite produced by the reactions described above occupies a smaller volume than the reactants occupied. Therefore, the reaction described above must not be responsible for the expansion. It is generally accepted that the expansion caused by sulfate attack is the result of particular mechanisms associated with the ettringite reaction or is the result of reaction other than the formation of ettringite. Gypsum, in addition to ettringite, can be produced during sulfate attack and is capable of producing expansion. Two particular mechanisms for expansion associated with the formation of ettringite have been widely published - the topochemical reaction mechanism and the swelling mechanism [11]. Sulfate attack 
can also take the form of a progressive loss of strength and loss of mass due to the loss of cohesiveness in the cement hydration products. The attack of sodium sulfates is performed as follow:

$$
\mathrm{Na} 2 \mathrm{SO} 4+\mathrm{Ca}(\mathrm{OH}) 2+2 \mathrm{H} 2 \mathrm{O} \rightarrow \mathrm{CaSO} 4.2 \mathrm{H} 2 \mathrm{O}+2 \mathrm{NaOH}
$$

The formation of sodium hydroxide as a byproduct of the reaction ensures the continuation of high alkalinity in the system, which is essential for the stability of the cementitious material C-S-H [12]. Several durability tests were conducted on self-cure concrete specimens by many researchers $[6,13]$. It was found that the initial surface absorption, chloride ingress, carbonation, corrosion potential and freeze/thaw resistance characteristics were all better in air cured self-cure concrete than in the air cured control concrete. It may be possible to achieve such properties with higher quantities of selfcure chemical admixtures. In this experimental program, the SC specimens were cast without any curing, while the conventional concrete specimens $\mathrm{CC}$, were cast by conventional procedures with substantial amount of curing water. To investigate the characteristics of compressive, tensile, flexure and bond strengths, samples were subjected to sulfate attack then tested.

\section{RESEARCH SIGNIFICANCE}

This research aims to investigate the long-term and durability performance of self-curing concrete SC compared to ordinary cured concrete CC subjected to sulfate attack. Main variable is sulfate attack time $(0,2,4$, and 6 months). The importance of this research is based on current research needs knowing the data addressing the long-term behavior of SC concrete. This research provides data for the engineers concerning the influence of using self-curing concrete in aggressive conditions, which contains sulfate ions.

\section{MATERIALS AND TEST SPECIMENS}

The following sections provide detailed description of the materials used, design of test specimens and testing procedures. The experimental program conducted in this study was performed in the laboratory of testing of building materials at the Faculty of Engineering, Menoufia University, Egypt. 


\subsection{MAterials}

CEMENT: The cement used was the ordinary Portland cement CEM I N42.5, from the Suez cement factory. Its chemical and physical characteristics satisfy the Egyptian Standard Specification [14].

FINE AGGREGATE: The fine aggregate used in the experimental program was the natural siliceous sand. Its characteristics satisfy the E.S.S 1109/2008 [15]. It was clean and nearly free from impurities with a specific gravity of $2.63 \mathrm{t} / \mathrm{m} 3$ and a fineness modulus of 2.52 . Its mechanical properties were shown in table (1) while its grading was shown in Table (1) and Fig. (1).

COARSE AGGREGATES: The coarse aggregate used was crushed dolomite, which satisfies the ASTM C33 Specification [16] with a specific gravity $2.70 \mathrm{t} / \mathrm{m} 3$ and a fineness modulus of 6.64 with a maximum nominal size of $12.5 \mathrm{~mm}$. The shape of these particles was irregular and angular with a relatively high percentage of elongated particles and a very low percentage of flat particles.

Table 1. Physical properties of the sand used

\begin{tabular}{|lr|c|}
\hline \multicolumn{2}{|c|}{ PROPERTY } & \multicolumn{1}{c|}{ VALUE } \\
\hline Specific gravity & $\left(\mathrm{t} / \mathrm{m}^{3}\right)$ & 2.63 \\
\hline Volumetric weight & $\left(\mathrm{t} / \mathrm{m}^{3}\right)$ & 1.61 \\
\hline Voids ratio & $(\%)$ & $40.3 \%$ \\
\hline Percent of clay, silt and dust & (by weight) & $0.5 \%$ \\
\hline
\end{tabular}

SILICA FUME: It is a waste by-product of silicon and silicon alloys industry consisting mainly of non-combustible amorphous silica ( $\mathrm{SiO} 2)$ particles. Egyptian Ferro Alloys Corporation (EFACO) produced it. The chemical components analysis was shown in Table (2) and main properties were shown in Table (3). The silica fume used was met the main requirements of ASTM C 1240.

Table 2. The Chemical Components Analysis Result of the Silica Fume Used

\begin{tabular}{|c|l|l|l|l|l|l|l|l|}
\hline $\begin{array}{c}\text { CHEMICAL } \\
\text { COMPOSITION }\end{array}$ & $\mathrm{SiO}_{2}$ & $\mathrm{Al}_{2} \mathrm{O}_{3}$ & $\mathrm{Fe}_{2} \mathrm{O}_{3}$ & $\mathrm{CaO}$ & $\mathrm{MgO}$ & $\mathrm{SO}_{3}$ & $\mathrm{~K}_{2} \mathrm{O}$ & L.O.I. \\
\hline AVERAGE (\%) & 95.93 & 0.52 & 0.05 & 0.2 & 0.18 & 0.1 & 0.4 & 2.9 \\
\hline
\end{tabular}

Table 3. Physical Properties of the Silica Fume Used

\begin{tabular}{|lc|c|}
\hline \multicolumn{2}{|c|}{ PROPERTY } & VALUE \\
\hline Specific gravity & $\left(\mathrm{t} / \mathrm{m}^{3}\right)$ & 2.21 \\
\hline Bulk density [uncompacted unit weight] & $\left(\mathrm{t} / \mathrm{m}^{3}\right)$ & 0.3 \\
\hline Fineness & $\left(\mathrm{m}^{2} / \mathrm{gm}\right)$ & 23.52 \\
\hline
\end{tabular}


SUPER-PLASTICIZER: The high-range water-reducing (HRWR) admixtures often referred to as super-plasticizers to help in increasing the workability of concrete without additional amount of water. A naphthalene sulphonate group based super-plasticizer, supplied by Chemicals for Modern Buildings (CMB) Company, and under the brand name of Addicrete BVF was chosen to be used in this study. Its main properties were shown in Table (4). The used super-plasticizer complies with ASTM C494 -Type F [17] and ESS 1899-1.

Table 4. Technical information of Addicrete BVF (as provided by manufacturer)

\begin{tabular}{|c|c|c|c|c|c|}
\hline BASE & Appearance & Density & $\begin{array}{c}\text { Chloride } \\
\text { content }\end{array}$ & Air entrainment & Compatibility \\
\hline $\begin{array}{l}\text { NAPHTALENE } \\
\text { SULPHONATE }\end{array}$ & Brown liquid. & $\begin{array}{c}1.18 \pm 0.01 \\
\mathrm{~kg} / \mathrm{liter}\end{array}$ & Nil & Nil & $\begin{array}{c}\text { All types of } \\
\text { Portland cement }\end{array}$ \\
\hline
\end{tabular}

CURING AGENT: The self-curing agent used in this study was Polyethylene glycol PEG200 as chemical agent in a liquid form for internal curing of concrete. It is free of chlorides and produces an internal membrane that protects and prevents fresh concrete against over-rapid water evaporation. Table (5) showed the characteristics of Polyethylene glycol PEG200 as produced by manufacturer. The PEG used was Polyethylene Glycol 200 that produced by Qualikems Fine Chemicals Pvt. Ltd.

Table 5. Technical information of Polyethylene Glycol 200 "PEG200" (as provided by manufacturer)

\begin{tabular}{|c|c|c|c|c|c|c|c|}
\hline \multirow{2}{*}{$\begin{array}{c}\text { Chemical } \\
\text { Curing } \\
\text { Agent }\end{array}$} & \multirow{2}{*}{$\begin{array}{c}\text { Average } \\
\text { molecular } \\
\text { weight }\end{array}$} & \multirow{2}{*}{$\begin{array}{c}\text { Hydroxyl } \\
\text { Number, } \\
\text { mg KOH/g }\end{array}$} & \multicolumn{3}{|c|}{ Liquid Density, g/cc } & \multirow{2}{*}{$\begin{array}{l}\text { Melting or Freezing } \\
\text { range }{ }^{\circ} \mathrm{C}\end{array}$} & \multirow{2}{*}{$\begin{array}{c}\text { Viscosity } \\
\text { at } \\
100^{\circ} \mathrm{C} \\
\text { cSt }\end{array}$} \\
\hline & & & $20^{\circ} \mathrm{C}$ & $60^{\circ} \mathrm{C}$ & $80^{\circ} \mathrm{C}$ & & \\
\hline PEG 200 & 190 to 210 & 535 to 590 & 1.1238 & 1.0921 & 1.0763 & $4-8^{\circ} \mathrm{C}$ & 4.3 \\
\hline
\end{tabular}

WATER: Drinkable clean water, fresh and free from impurities was used for mixing and curing the tested samples according to the Egyptian code of practice [18].

STEEL: Deformed high tensile steel bars of grade 360/520 with a nominal diameter of $16 \mathrm{~mm}$ and length of $160 \mathrm{~mm}$ were used as individual rebars and as embedded reinforcement with a proof stress of $360 \mathrm{MPa}$. Its mechanical characteristics satisfy the Egyptian Standard Specification (E.S.S. 262/ 1999). 


\subsection{CONCRETE AND TEST SAMPLES}

Two concrete mixes were proportioned. The first concrete mix SC was self-curing concrete based on previous researches [5, 19, 6, 20]. Samples were cast using ordinary Portland cement, crushed dolomite with a maximum nominal size of $12.5 \mathrm{~mm}$, graded sand with a fineness modulus of 2.40 , silica fume as $15 \%$ of cement content, super-plasticizer "Addicrete BVF" as $0.07 \%$ of cement content $[20,6]$, chemical curing agent "Poly ethylene glycol PEG200" as 2\% of cement content [5] and tap water for the first concrete mix. The second concrete mix CC is normally cured concrete mix with the same proportions of the self-curing concrete mix but without additional chemical curing agent "PEG200" to produce the possibility to compare between the both mixtures. Samples were cast using two used concrete mixtures SC and CC. The second concrete mix CC was cured for 28 days.

Table 6. Concrete mixes used

\begin{tabular}{|c|c|c|c|c|c|c|c|}
\hline Mix. & $\begin{array}{c}\text { Cement } \\
\mathrm{kg} / \mathrm{m}^{3}\end{array}$ & $\begin{array}{l}\text { Water } \\
\mathrm{kg} / \mathrm{m}^{3}\end{array}$ & $\begin{array}{l}\text { Sand } \\
\mathrm{kg} / \mathrm{m}^{3}\end{array}$ & $\begin{array}{c}\text { Dolomite } \\
\mathrm{kg} / \mathrm{m}^{3}\end{array}$ & $\begin{array}{l}\text { Silica fume } \\
\mathrm{kg} / \mathrm{m}^{3}\end{array}$ & $\begin{array}{c}\text { Super- } \\
\text { plasticizer } \\
\mathrm{kg} / \mathrm{m}^{3}\end{array}$ & $\begin{array}{c}\text { Chemical Agent } \\
\text { PEG200 } \\
\mathrm{kg} / \mathrm{m}^{3}\end{array}$ \\
\hline $\mathrm{SC}$ & \multirow{2}{*}{300} & \multirow{2}{*}{$\begin{array}{c}150 \\
\text { (as } 50 \% \mathrm{C} \text { ) }\end{array}$} & \multirow{2}{*}{643} & \multirow{2}{*}{1193} & \multirow{2}{*}{$\begin{array}{c}45 \\
\text { (as } 15 \% \mathrm{C} \text { ) }\end{array}$} & \multirow{2}{*}{$\begin{array}{c}2.1 \\
\text { (as } 7 \% \text { C) }\end{array}$} & $6(2 \% C)$ \\
\hline $\mathrm{CC}$ & & & & & & & \\
\hline
\end{tabular}

For each concrete mix, fifteen cube specimens, 100x100x100 mm, were prepared for evaluating the compressive strength. Fifteen cylindrical concrete specimens, $100 \mathrm{~mm}$ in diameter and $200 \mathrm{~mm}$ high, were prepared to evaluate the split tensile strength. They were tested for split tensile strength according to E.C.P. 203/2007 [18]. The flexural strength was determined according to ASTM C 293 using a mid-point loading method utilizing using fifteen 100x100x500 mm prismatic concrete specimens. To obtain bond strength, reinforcing bar push-down tests were conducted at various ages of concrete, starting from the setting time of concrete at 28 days to 6 months days under sulfate attack and values were compared. Steel rebars (St.52) of $16 \mathrm{~mm}$ diameter were cut into $16 \mathrm{~cm}$ length specimens then they embedded in 150x150x150 mm concrete cubes during casting process. The bond properties of reinforcing bars in SC were studied by conducting direct push-down test of reinforcing bars embedded in SC specimens and also in CC specimens and the results are compared. The concrete-steel bond strength is formulated according to E.C.P. 203/2007 [18] as Fbu= fs . $\varphi /(4 . L d)$ where, $\mathrm{Ld}(\mathrm{mm})$ is bond length of steel; $\varphi(\mathrm{mm})$ is the diameter of the steel; and $\mathrm{fs}(\mathrm{N} / \mathrm{mm} 2)$ is the 
tensile stress in steel. If in the previous equation $\mathrm{fs}=\mathrm{F} /(\pi . \varphi 2 / 4)$, where $\mathrm{F}(\mathrm{N})$ is the applied force on the rebar, it then comes out as, $\mathrm{Fbu}=\mathrm{F} /(\mathrm{Ld} . \pi . \varphi)$. Three specimens representing same constituent were used for each test throughout this study and the average values were reported. The samples of each were tested after 28 and after 56 days to determine the main mechanical properties for each mix including the compressive strength (fcu), tensile strength ( $\mathrm{ft}$ ), and modulus of rupture (fr) as well as bond strength. Table (7) shows the mechanical properties of the two mixes at 28 and 56 days.

Table 7. Main mechanical properties of used concrete at tests of 28 days

\begin{tabular}{|c|c|c|c|c|}
\hline \multicolumn{2}{|c|}{ Mix. } & $\begin{array}{c}\text { Compressive } \\
\text { strength } \\
M P a\end{array}$ & $\begin{array}{c}\text { Splitting } \\
\text { Tensile strength } \\
M P a\end{array}$ & $\begin{array}{c}\text { Flexural strength } \\
M P a\end{array}$ \\
\hline \multirow{2}{*}{ SC } & 28 days & 43 & 4.25 & 8.93 \\
\cline { 2 - 5 } & 56 days & 35.2 & 4.55 & 9.1 \\
\hline \multirow{2}{*}{ CC } & 28 days & 48 & 4.78 & 9.68 \\
\cline { 2 - 5 } & 56 days & 50 & 4.95 & 9.9 \\
\hline
\end{tabular}

\subsection{SULFATE ATTACK SIMULATION}

The samples were immersed in sodium sulfate Na2SO4 solution. The amounts of added sulfates were computed to provide total dissolving sulfate ions of $4 \%$ concentration solution. It is worth mentioning that the selected concentration of sulfate ions was 10 times higher than that allowed by the E.C.P. 203/2007 [18] in order to accelerate the sulfate attack mechanism. The samples were immersed in that solution for 2, 4 and 6 months and then tested. Results were compared to control specimens. Crystals of salt were seen on the surface of samples due to evaporation of the solution. During this test both temperature and relative humidity were measured once a week. Statistical results showed that the temperature varied in the range $24-32 \mathrm{oC}$ with an average of $28 \mathrm{oC}$, while the relative humidity varied in the range $65-73 \%$ with an average of $69 \%$. 


\section{TEST RESULTS AND DISCUSSIONS}

\subsection{COMPRESSIVE STRENGTH TEST RESULTS}

The compressive strength results are shown in Fig. 2 as a function of exposure time to sulfate attack. It shows the variation in the cube compressive strength with time for SC concrete specimens, which were immersed in a $0.04 \mathrm{~g} / \mathrm{ml} \mathrm{Na} 2 \mathrm{SO} 4$ solution (4\% concentration) for 2, 4 and 6 months compared to $\mathrm{CC}$ concrete specimens at the same conditions. The first measurements of compressive strength were unable to show any significant changes in the mechanical properties of the specimens within the first 2 months of sulfate exposure time under the specific conditions adopted in this work.

Samples of conventional curing CC concrete are more sensitive to sulfate effect comparing to selfcuring SC concrete samples. That can be attributed to the presence of pores in $\mathrm{CC}$ concrete compared to SC concrete. For less than 2 months of immersion, the differences in the compressive strength of the specimens were small. The compressive strength is increased by about 3.5 and $4.2 \%$ for SC and $\mathrm{CC}$ concretes respectively. This result can be explained by the simultaneity of calcium hydroxide dissolution and C-S-H decalcification with sulfate diffusion in concrete, where the dissolution and decalcification dominated at early immersion times. However, after 6 months of immersion, the highest sulfate concentration was observed for CC specimens, whereas the SC specimens exhibited the lowest sulfate concentrations and with maximum loss of compressive strength by about 14 and $20 \%$ for SC and CC concretes respectively. After 6 months, the compressive strength of SC and CC samples decreased. Samples became denser and thus the micro-structure was positively modified. The cracks have been observed when a continual load is applied to specimens because the enlargement of the channels for sulfate diffusion into concrete which increases the sulfate diffusion rate.

Figure 2 clearly shows that the compressive strength test results of the SC and CC samples exposed to sulfate. It consisted of two stages, an initial increasing stage of up to 2 months and a declining stage. This behavior can be attributed to the transport of sulfate ions into the pores of concrete where they reacted with hydration products to form expansive materials that blocked the pores, resulting in the development of micro-cracks and an interfacial transition zone at early immersion times; consequently, the SC and CC became with more close pores and hence, the strength of the SC and $\mathrm{CC}$ specimens increased. However, when the concrete pores cannot provide the material expansion, the concrete properties are negatively impacted. In particular, if the volume of the expansive material produced by the sulfate ions is much greater than the pore volume, internal expansion stresses can 
create both micro- and macro-cracks. Thus, the strength decreased in the late stages of the specimen immersion in the $\mathrm{Na} 2 \mathrm{SO} 4$ solution.

The strength loss increased as the exposure time increased. Thus, using self-curing agent prevented the ingress of sulfate into the concrete, whereas the sulfate diffusion rate increased in conventional cured concrete. These results are in an agreement with the observations of Emam (2012) and Vyawahare et al., (2014) [6,13] discarding using different curing agents.
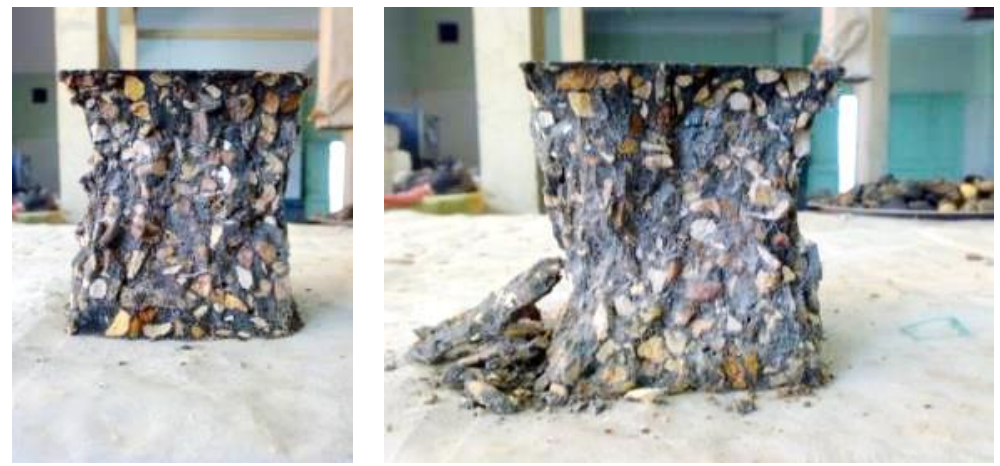

Fig. 1. SC samples after compressive strength test and immersion time for 6 months.

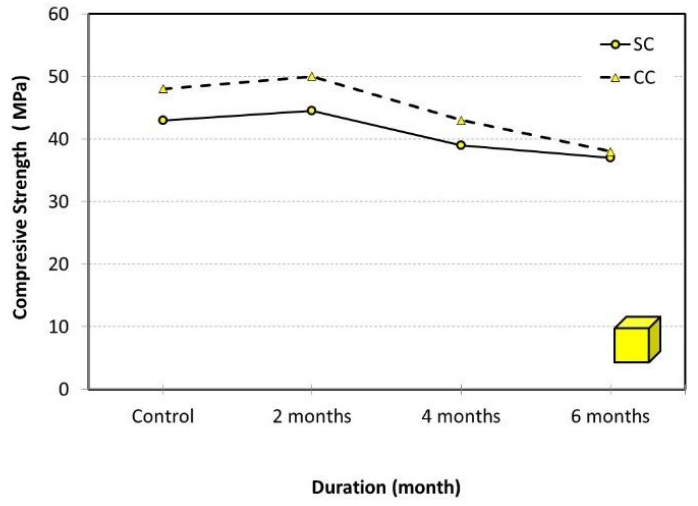

Fig. 2. Sulfate effect on compressive strength values of SC and CC samples. 


\subsection{SPlitTing Tensile TeSt RESUlts}

Figure 3 shows examples of tensile strength measurements as a function of exposure time to sulfate attack. It shows the variation in the cylinder indirect tensile strength with time for SC specimens, which were immersed in a $0.04 \mathrm{~g} / \mathrm{ml} \mathrm{Na} 2 \mathrm{SO} 4$ solution ( $4 \%$ concentration) for 2,4 and 6 months. The results showed that the sulfate concentration at the specimens in all of the environments increased with the immersion time. Thus, sulfate diffused freely into the concrete from the external sulfate solution. The both types of concretes, $\mathrm{CC}$ and SC concretes, nearly behave the same in indirect tensile test as it behave in compression test. For 2 months of immersion, the tensile strength is increased by about 3.5 and $6.7 \%$ for SC and CC concretes respectively. However, after 4 months the tensile strength decreased by about 5 and $7 \%$ for SC and CC concretes respectively. After 6 months of immersion, the highest sulfate concentration was observed for CC specimens, whereas the SC specimens showed the lowest sulfate concentrations and with maximum loss of compressive strength by about 8 and $13.4 \%$ for SC and CC concretes respectively. The strength loss was increased as the exposure time increased.

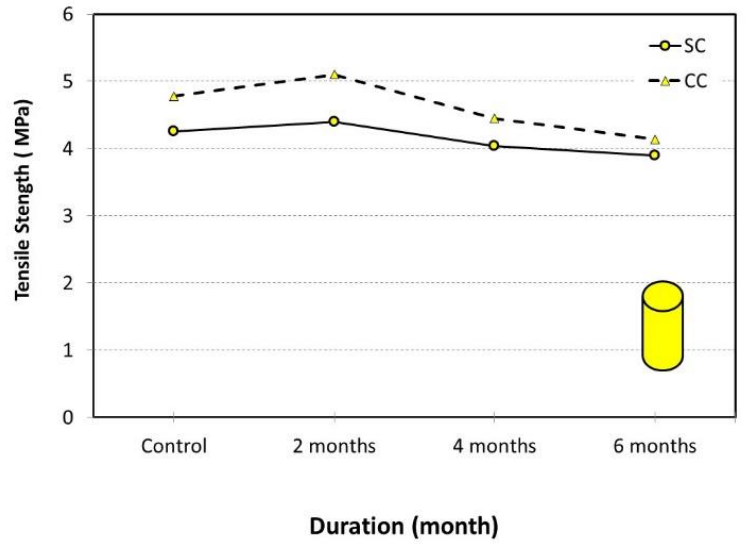

Fig. 3. Sulfate effect on indirect tensile strength values of SC and CC samples.

As a result, the strength decreased in the late stages of the specimen immersion in the Na2SO4 solution. These results agreed with those of Wang et al. [21, 22]. 


\subsection{Flexural TeSt Results}

The flexural strength results are shown in Fig. 4. The both types, CC and SC concretes, nearly behave the same in flexure. For 2 months of immersion, the flexural strength is increased by about 1.9 and $2.3 \%$ for SC and CC concretes respectively. However, after 4 months the tensile strength decreased by about 3 and $16 \%$ for SC and CC concretes respectively. After 6 months of immersion, the highest sulfate concentration was observed for CC specimens, whereas the SC specimens exhibited the lowest sulfate concentrations and with maximum loss of compressive strength by about 5 and $22 \%$ for SC and CC concretes respectively. The strength loss was increased as the exposure time increased.

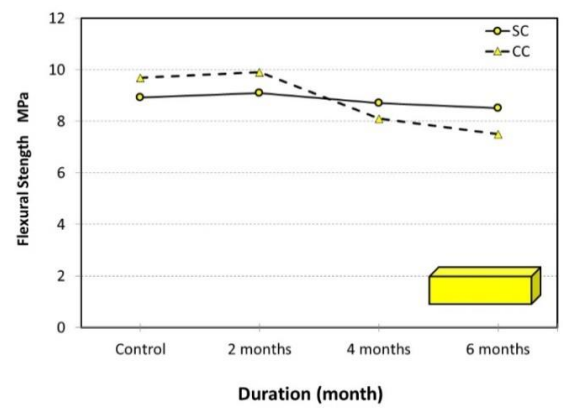

Fig. 4. Sulfate effect on flexure strength values of SC and CC samples

As a result, the strength decreased in the late stages of the specimen immersion in the Na2SO 4 solution. These results agreed with those of Wang et al. (2013) [22] for CC samples and nearly agreed with Emam (2012) [6] for SC samples.

\subsection{EFFECTS ON CONCRETE MASS}

No significant visible damage was detected with lower sulfate exposure time. Damages with higher exposure time were a little more severe but always related to the specimen's surface only.

The damage - as detected by visual observation -if any, deals with the skin of the specimens and then causes only negligible changes in main mechanical properties related to the whole mass of the specimens as shown in Fig. 5. However in real concrete structures the sulfate attack can become more severe because of micro cracks (caused by restrained thermal and drying shrinkage or loading in service) which favor a deeper penetration of sulfate into the cement matrix. Results are in agreed with Lee et al., (2015) [23]. 


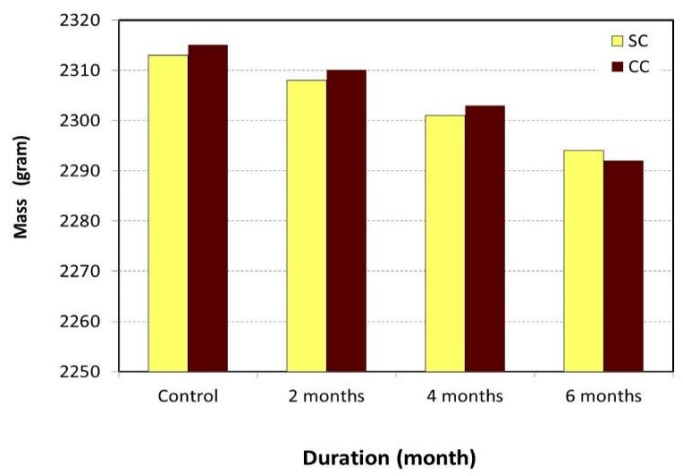

Fig. 5. Mass loss of SC and CC samples due to sulfate attack.

\subsection{EFFECTS ON BOND STRENGTH}

Figure 6 showed the behavior of bond strength values of SC compared to CC concrete samples after different periods of sulfate attack. Results have shown that the bond strength values are improved in both samples, SC and CC, with improving values up to $16 \%$. The behavior in both types are nearly the same. That enhancement may be referred to the internal expansion of sulfates which cause higher pressure of cement matrix on bars that led to higher friction between matrix and bars during bond test. Also, it may be referred to the insufficient duration to notice the sulfate effect on concrete samples.

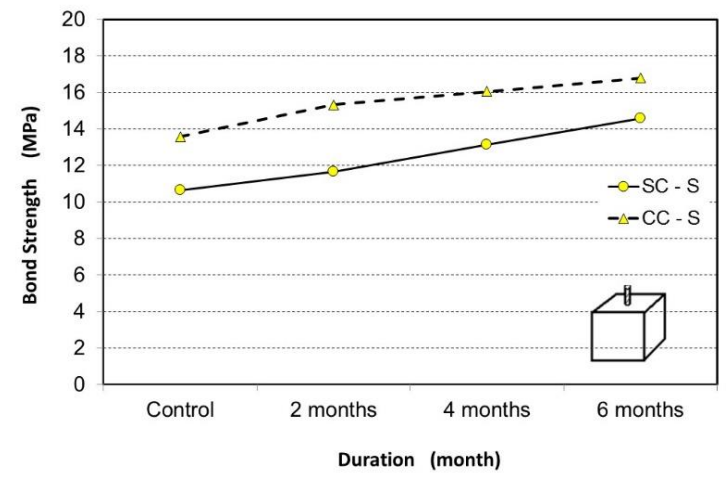

Fig. 6. Bond strength of SC and CC samples due to sulfate attack 


\section{Conclusions}

Based on the results obtained from the current research, the following main conclusions can be summarized:

1. Self-curing concrete behaved nearly identical to the same CC concrete but the self-curing SC concrete with chemical curing agent gives less strength values by about $8-10 \%$ comparing to conventional curing $\mathrm{CC}$ concrete.

2. Samples of conventional curing $\mathrm{CC}$ concrete are more sensitive to sulfate attack in comparison to the self-curing SC concrete samples especially when increasing exposure time.

3. The strength loss was increased as the exposure time increased but bond strength has improved (in the range of this study).

4. The durability is not affected much by using chemical curing agents for internal curing.

5. The relationship between bond strength and compressive strength of $\mathrm{CC}$ concrete is more consistent than SC.

Finally, it is noticed that normal curing method seems to be the better method for curing providing satisfactory strength and durability $[24,13]$. By using internal curing agents also we can achieve almost $90 \%$ strength and durability achieved by normal curing method without much attention. There is not major strength loss. Self-curing concrete can be used in urban areas of aggressive weather. 


\section{REFERENCES}

1. B. Mather, "Self-Curing Concrete, Why Not?," Concrete International 23(1): 46-47, 2001.

2. R. K. Dhir, P. C. Hewlett, J. S. Lota and T. D. Dyer, "An Investigation into the Feasibility of Formulating Selfcure Concrete," Materials and Structures/Materiaux et Constructions 27(74): 606-615, 1994.

3. R. K. Dhir, P. C. Hewlett and T. D. Dyer, "Mechanisms of Water Retention in Cement Pastes Containing a Selfcuring Agent," Materials and Structures/Materiaux et Constructions 50(1): 85-90, 1998.

4. M. Geiker, D. Bentz and O. Jensen, "Mitigating Autogenous Shrinkage by Internal Curing," High Performance Structural Lightweight Concrete," American Concrete Institute, pp. 143-150, 2004.

5. A. S. EL-Dieb, "Self- Curing Concrete: Water Retention, Hydration and Moisture Transport," 21: 1282-1287, 2007.

6. E. A. Emam, Durability of Self-Curing Concrete, M.Sc., Faculty of Engineering, Menoufia University, Egypt, 2012 .

7. T. Hammer, O. Bjontegaard and E. Sellevold, "Internal Curing Role of Absorbed Water in Aggregates, Highperformance Structural Lightweight Concrete," ACI fall convention, ACI SP 218, 2002.

8. D. Bentz, P. Lura and J. Roberts, "Mixture Proportioning for Internal Curing," Concrete International 27(2): 35 $40,2005$.

9. I. Odler and I. Jawed, "Expansive Reactions in Concrete," Materials Science of Concrete 2: 221-247, 1991

10. O. S. Baghabra, "Sulfate Attack and Reinforcement Corrosion in Plain and Blended Cements Exposed to Sulfate Environments," Building and Environement 33(1): 53-61, 1998.

11. P. Mehta, "Sulfate Attack on Concrete - A Critical Review," Materials Science of Concrete III, pp. 105-130, 1992.

12. P. Mehta and P. Monteiro, Concrete Structure, Properties and Materials, New Jersey: Prentice Hall, 1993.

13. M. R. Vyawahare and A. A. Patil, "Comparative study on Durability of Self cured SCC and Normally cured SCC," International Journal of Scientific Research Engineering \& Technology (IJSRET) 3(8): 1201-1208, 2014.

14. E.S.S.4756-1/2009, "Portland Cement, Ordinary and Rapid Hardening," Ministry of Industry, Cairo, Egypt, 2009.

15. E.S.S.1109/2008, "Aggregate," Ministry of Industry, Cairo, Egypt, 2008.

16. ASTM.C-33, "Aggregates," American Society for Testing and Materials ASTM International, Philadelphia, USA, 2003.

17. ASTM.C-494, "Chemical Admixtures," American Society for Testing and Materials ASTM International, Philadelphia, USA., 2003.

18. E.C.P.203/2007, "Egyptian Code of Practice: Design and Construction for Reinforced Concrete Structures," Research Centre for Houses Building and Physical Planning, Cairo, Egypt, 2007.

19. A. EL-Dieb and S. Okba, "Performance of Self Curing Concrete," Ain Shams University, Cairo, Egypt., Cairo, Egypt, 2005.

20. A. A. Bashandy, "Performance of Self-curing Concrete at Elevated Temperatures," Indian Journal of Engineering and Materials Sciences 22: 93-104, 2015.

21. H. Wang, Y. Dong, X. Sun and W. Jin, "Damage Mechanism of Concrete Deteriorated by sulfate attack in wetdry cycle environment," Journal of Zhejiang University (Engineering Science) 46(7): 1255-1261, 2012.

22. J. Gao, Z. Yu, L. Song, T. Wang and S. Wei, "Durability of Concrete Exposed to Sulfate Attack under Flexural Loading and Drying-wetting Cycles," Construction and Building Materials 39(7-9): 33-38, 2013.

23. K. M. Lee, S. H. Bae, J. I Park and K. S. O., "Mass Change Prediction Model of Concrete Subjected to Sulfate Attack," Mathematical Problems in Engineering 2015: 1-10, 2015.

24. M.S. Ravikumar, C. Selvamony, S.U. Kannan and B. G. .S, "Self Compacted / Self Curing / Kiln Ash Concrete," International Journal on Design and Manufacturing Technologies 5(1), 2011. 


\section{LIST OF FIGURES AND TABLES:}

Fig. 1. SC samples after compressive strength test and immersion time for 6 months

Rys. 1. Próbki SC po próbie wytrzymałości na ściskanie oraz czasie zanurzenia 6 miesięcy

Fig. 2. Sulfate effect on compressive strength values of SC and CC samples

Rys. 2. Wpływ siarczanu na wartości wytrzymałości na ściskanie próbek SC i CC

Fig. 3. Sulfate effect on indirect tensile strength values of SC and CC samples

Rys. 3. Wpływ siarczanu na pośrednie wartości wytrzymałości na ściskanie próbek SC i CC

Fig. 4. Sulfate effect on flexure strength values of SC and CC sample

Rys. 4. Wpływ siarczanu na wartości wytrzymałości na zginanie próbek SC i CC

Fig. 5. Mass loss of SC and CC samples due to sulfate attack

Rys. 5. Strata masy próbek SC i CC z powodu skażenia siarczanem

Fig. 6. Bond strength of SC and CC samples due to sulfate attack

Rys. 6. Siła wiązania próbek SC i CC z powodu skażenia siarczanem

Tab. 1. Fizyczne właściwości użytego piasku

Tab. 1. Physical properties of the sand used

Tab. 2. Wynik Analizy Składników Chemicznych Użytego Pyłu Krzemionkowego

Tab. 2. The Chemical Components Analysis Result of the Silica Fume Used

Tab. 3. Fizyczne Właściwości Użytego Pyłu Krzemionkowego

Tab. 3. Physical Properties of the Silica Fume Used

Tab. 4. Informacje techniczne o Addicrete BFV

Tab. 4. Technical information of Addicrete BVF (as provided by manufacturer)

Tab. 5. Informacje techniczne o Glikol Polietylenowy 200 "PEG200"

Tab. 5. Technical information of Polyethylene Glycol 200 "PEG200" (as provided by manufacturer)

Tab. 6. Użyte mieszanki betonu

Tab. 6. Concrete mixes used

Tab. 7. Główne właściwości mechaniczne użytego betonu w testach $28 \mathrm{dni}$

Tab. 7. Main mechanical properties of used concrete at tests of 28 days 


\section{BETON SAMO-UTWARDZALNY SKAŻONY SIARCZANEM}

Słowa kluczowe: samoutwardzalny, glikol polietylenowy, siarczan, trwałość, beton

\section{STRESZCZENIE:}

Niniejsza praca przedstawia wyniki badania przeprowadzonego w celu ocenienia wpływu siarczanów na beton samoutwardzalny, w porównaniu z betonem zwykłym.

Beton samoutwardzalny SC, jest typem betonu, który utwardzany jest bez jakichkolwiek zewnętrznych systemów utwardzania. Można to osiągnąć stosując kilka metod, jak użycie lekkiego kruszywa, czy też środków chemicznych. W tym badaniu, do produkcji SC wykorzystano chemiczny środek utwardzający.

Przygotowano dwie mieszanki betonu. Pierwszą mieszanką SC był beton samo-utwardzalny oparty na poprzednich badaniach. Próbki zostały odlane przy wykorzystaniu zwykłego cementu portlandzkiego, zgniecionego dolomitu o maksymalnym rozmiarze nominalnym $12,5 \mathrm{~mm}$, sortowanego piasku ze współczynnikiem delikatności 2,40, pyłem krzemionkowym jako 15\% zawartości cementu, super-plastyfikatorem "Addicrete BVF" jako 0,07\% zawartości cementu, chemicznym utwardzaczem "Glikolem polietylenowym PEG200" jako 2\% składniku cementu oraz z wodą kranową do pierwszej mieszanki betonu. Druga mieszanka betonu CC, jest zwyczajnie utwardzaną mieszanką, o tych samych proporcjach co mieszanka samoutwardzająca, ale bez dodatku chemoutwardzacza "PEG200", aby dać możliwość porównania obu mieszanek. Próbki zostały odlane przy wykorzystaniu dwóch użytych mieszanek, SC i CC. Drugą mieszanką betonu była CC, utwardzana przez 28 dni.

Dla każdej mieszanki, piętnaście sześciokątnych próbek, 100x100x100 mm, zostało przygotowanych do oceny wytrzymałości na ściskanie. Piętnaście cylindrycznych próbek betonowych, o średnicy $100 \mathrm{~mm}$ i wysokości $200 \mathrm{~mm}$, zostało przygotowanych, aby ocenić wytrzymałość na rozciąganie. Poddano je badaniom na wytrzymałość na rozciąganie, według E.C.P. (Europejska Platforma Betonu). 203/2007. Wytrzymałość na zginanie została ustalona według ASTM C293, wykorzystując środkowy punkt obciążenia, przy użyciu piętnastu pryzmatycznych próbek betonowych, 100x100x500 mm. Aby otrzymać siłę wiązania, w różnych etapach zastygania betonu, przeprowadzono badanie wciskając pręty zbrojeniowe, poczynając od stwardnienia betonu po 28 dniach, do 6 miesięcy od skażenia siarczanem, a następnie porównano wartości. Stalowe pręty zbrojeniowe (St.52), śr. $16 \mathrm{~mm}$, zostały pocięte na $16 \mathrm{~cm}$ próbki, a następnie osadzone w betonowych kostkach 150x150x150 mm, w trakcie procesu odlewania. Właściwości wiązania prętów zbrojeniowych w SC zostały zbadane przez przeprowadzenie bezpośredniego badania wciskowego prętów zbrojeniowych osadzonych w próbkach SC oraz w próbkach CC, a wyniki zostały porównane.

Próbki zostają zanurzone w 4\% roztworze siarczanu sodu Na2SO4. Wyniki są porównywane pod kątem wytrzymałości na ściskanie, rozciąganie, zginanie oraz utraty masy.

Okazało się, że tempo utraty wytrzymałości zauważyć można w betonie zwykłym, w porównaniu z betonem SC. Odporność na siarczany jest zwiększona poprzez wykorzystanie betonu samoutwardzalnego. To udoskonalenie zdaje się być zależne od wykorzystania czynnika utwardzającego. Zauważono, że normalna metoda utwardzania wydaje się lepszą metodą, dającą zadowalającą odporność oraz trwałość. Poprzez wykorzystanie wewnętrznych czynników utwardzających, możemy osiągnąć prawie 90\% wytrzymałości oraz trwałości osiąganej przez normalne metody utwardzania, bez większego wysiłku. Nie nastąpiła poważna utrata odporności. 